Meta

Journal des traducteurs

Translators' Journal

\title{
A Short Condominium Lexicon
}

\section{Wallace Schwab}

Volume 37, numéro 3, septembre 1992

URI : https://id.erudit.org/iderudit/004066ar

DOI : https://doi.org/10.7202/004066ar

Aller au sommaire du numéro

Éditeur(s)

Les Presses de l'Université de Montréal

ISSN

0026-0452 (imprimé)

1492-1421 (numérique)

Découvrir la revue

Citer ce document

Schwab, W. (1992). A Short Condominium Lexicon. Meta, 37(3), 537-539.

https://doi.org/10.7202/004066ar

Ce document est protégé par la loi sur le droit d'auteur. L'utilisation des services d'Érudit (y compris la reproduction) est assujettie à sa politique d'utilisation que vous pouvez consulter en ligne.

https://apropos.erudit.org/fr/usagers/politique-dutilisation/
Cet article est diffusé et préservé par Érudit.

Érudit est un consortium interuniversitaire sans but lucratif composé de l'Université de Montréal, l'Université Laval et l'Université du Québec à Montréal. Il a pour mission la promotion et la valorisation de la recherche. https://www.erudit.org/fr/ 


\section{A SHORT CONDOMINIUM LEXICON}

As condominiums have become a part of our insurance, legislative and real estate realities, the words and expressions used to describe them have also taken root in our vocabulary. In mastering the concepts that depict condominiums and the people who live in such dwellings, we note differences between the Québec Civil Law vocabulary and the common law terms characteristic of the rest of North America.

Any attempt to inventory this lexical treasure must cope with some unusual difficulties, namely that the current updating of the Québec Civil Code can be a source of unsuspected confusion because terms used in the current Civil Code are sometimes replaced by others in the soon-to-be-effective Civil Code. To play it safe, we have first 
listed the stable French terms as the anchor and then have presented the English equivalents in the following order:

French term: general or common law equivalent(s); current Civil Code equivalent; new Civil Code equivalent; but if there is only one English term for all three or if Québec law is silent on such matters, a single term appears by itself.

One final word of caution: translated documents travelling between civil law and common law jurisdictions may sometimes be the unintended vehicles of concepts or causes of action (especially those involving equitable or fiduciary relationships) that are unknown, invalid or even worse, far more potent than in the "other" jurisdiction. To be on the safe side, consult your lawyer or notary before attempting to enforce a contract that you have had "translated"... you could be in for a surprise!

amélioration

appartement

assurance de la collectivité

des copropriétaires

assurance du bâtiment

assurance du contenu

assurance du copropriétaire

collectivité

collectivité des copropriétaires

copropriétaire

copropriété

copropriété par déclaration

copropriété divise

copropriété indivise

coût de remplacement

déclaration de copropriété

franchise

habitation

immeuble en copropriété par déclaration

immeuble par destination

indivision

\section{betterment}

unit

condominium corporation policy

policy on (the) building

policy on (the) contents

unit owner's policy

condominium corporation

condominium corporation

unit owner or tenant in common; coproprietor; co-owner

individual ownership or tenancy in common; co-ownership; co-ownership

condominium

divided co-ownership

undivided co-ownership

replacement cost

condominium declaration, co-ownership declaration; declaration of co-ownership; declaration of co-ownership

deductible (clause)

unit

condominium building

permanently installed (then enumerate items) indivision or undivided interest; indivision; indivision 
jour du sinistre

lot

partie commune

partie exclusive

partie privative date of loss

lot, strata lot or condominium parcel; lot; lot common area or element; common portion; common part

unit-owner area, condominium parcel, individual unit, strata lot; exclusive portion; exclusive part

(See partie exclusive)

Note: The designation of the unit-owner's area goes by many expressions in English which can be quite confusing for the uninitiated. My advice is to treat any document as a whole and interpret it by opposing one term with another (while hoping that the author did not use synonyms carelessly...).

plus-value de (l'article)

règle proportionnelle

remise en état

répartition

sinistre

société de copropriété

valeur à neuf

valeur au jour du sinistre excess cost of (item)

co-insurance provision or co-insurance clause

restoration

apportionment

loss(es)

association of unit owners, condominium corporation, trust, unincorporated association, partnership or strata corporation; not found; syndicate (which is a legal person, i.e. corporation)

replacement cost

actual cash value

WALLACE SCHWAB

Les services Maurepas, Sainte-Foy, Canada 